ascorbic acid delays epithelialization because of the tardy formation of a satisfactory collagenous base for the regenerating epithelium.

One of us, N. M. G., carried out this work while in receipt of a Roche Scholarship tenable at University College, Dundee, and we are all indebted to Roche Products Ltd. for generous supplies of various preparations of ascorbic acid.

\title{
RFFERENCES
}

Bourne, G. H. (1944). Lancet, 246, 688 .

Campbell, H. G. \& Cook, R. P. (1942). Brit. dent. F. 72, 6.

Crandon, J. H., Lund, C. C. \& Dill, D. B. (1940). New Engl. F. Med. 223, 353.

Cuthbertson, D. P., Shaw, G. B. \& Young, F. G. (194I). F. Endocrinol. 2, 475.

Duke-Elder, W. S. (1946). Textbook of Ophthalmology, 2. London: Henry Kimpton.

Hartwell, S. W. (1929). Arch. Surg., Chicago, 19, 835.

Hunt, A. H. (1941). Brit. F. Surg. 28, 436.

'Student' (1008). Biometrika, 6, $\mathrm{x}$.

'Student' (1925). Metron, 5, 105.

Thomson, W. (1936). F. Hyg., Camb., 36, 24.

Wolbach, S. B. \& Howe, P. R. (1926). Arch. Path. Lab. Med. r, I.

\section{Comparison of Nutrient Values of Individual Diets Found by Calculation from Food Tables and by Chemical Analysis}

\author{
By E. R. BRANSBY, Ministry of Health, Whitehall, London, S.W. I \\ AND C. G. DAUBNEY AND J. KING \\ Department of the Government Chemist, Strand, London, W.C. 2
}

(Received I9 May 1948)

Comparison of the results obtained by different methods of individual survey (Bransby, Daubney \& King, 1948) showed considerable differences between the nutrient values of diets obtained by calculation from food tables and by chemical analysis. It was suggested that this may have arisen because the inquiry was made in a single children's home. This paper gives the results of a comparison between the nutrient values of a number of individual diets eaten by persons living at home, found by calculation from food tables and by chemical analysis. One of us (E. R. B.) was responsible for the planning and execution of the inquiry, while two of us (C. G. D., J. K.) were responsible for the chemical analysis of the diets.

\section{EXPERIMENTAL}

Plan of experiment. Records of the weights of food eaten in 3 days were obtained from thirty-three adults living at home in Cambridge, Reading, London and Surrey. Duplicates of the same diets were collected for chemical analysis. Those co-operating 
in the inquiry were enlisted because of their scientific training and ability to carry out the work satisfactorily. Written instructions were issued and the method of survey was explained verbally before the inquiry began, and the recording was checked as the work proceeded. The duplicate diets were put in Kilner jars and kept in refrigerators until ready for chemical analysis. Those collaborating in the inquiry were reimbursed to cover the cost of the food provided and given temporary ration cards to compensate for the rationed foods in the duplicate diets.

Chemical analysis. The 3-day diets of each person were mixed and analysed for moisture, ash, calcium, iron, nitrogen, fat, sugar and starch by the methods previously described (Bransby et al. 1948).

Food tables. The nutrients in the diets were calculated from food tables based on values given in Nutritive Values of Wartime Foods (Accessory Food Factors Committee, 1945) and The Chemical Composition of Foods (McCance \& Widdowson, 1946), and on values for made-up dishes from recipes conforming to present food conditions.

As before (Bransby et al. 1948) the purpose of the inquiry was not to evaluate the basic data of food tables or to discuss the methods of calculating the energy values of foods or diets, but to compare nutrient values as found by different survey methods. In order that the comparison might be confined to differences between the values found by calculation from food tables and by chemical analysis, the starch values found by analysis were increased for the calculations of the calorie value of the diets by $21 \%$ for the reasons previously explained (Bransby et al. 1948).

\section{RESULTS}

Table I gives the average daily nutrient values for each of the thirty-three diets by calculation from food tables and by chemical analysis. Table 2 gives the average values for the thirty-three diets taken together and the average percentage differences between the results obtained by the two methods. Table 3 shows the frequency distribution of the percentage differences for the thirty-three diets.

Table 2 shows that the absolute and percentage differences between the average nutrient values found by the two methods of survey are statistically significant for protein, carbohydrate and iron, but not for calories or fat. For calcium only percentage difference is significant. The differences for protein and carbohydrate are so small as to make them unimportant for most practical purposes. For iron, however, the difference is large. Table 3 shows that for many of the diets there are considerable differences between the values found by calculation and those found by analysis. Thus the difference is $10 \%$ or more for sixteen, fifteen, eleven, twenty-three and thirty-two of the thirty-three diets for protein, fat, carbohydrate, calcium and iron, respectively; for three, seven, one, nine and twenty-nine diets the difference is $20 \%$ or more. Agreement is better for calories; for twenty-seven of the thirty-three diets the difference is less than $10 \%$. The agreement for calories is better than for protein, fat or carbohydrate because an overestimate of the energy derived from one nutrient is counterbalanced by an underestimate of that from another. 
Table 1. Daily nutrient values of diets eaten by thirty-three adults, obtained by calculation from food tables and by chemical analysis

Subject Method

\begin{tabular}{|c|c|c|c|c|c|c|c|c|c|c|}
\hline No. & Sex & $\begin{array}{c}\text { of } \\
\text { survey }\end{array}$ & Calories & $\begin{array}{l}\text { Protein } \\
\text { (g.) }\end{array}$ & $\begin{array}{l}\text { Fat } \\
\text { (g.) }\end{array}$ & $\begin{array}{c}\text { Carbohydrate } \\
\text { (g.) }\end{array}$ & $\begin{array}{l}\text { Sugar } \\
\text { (g.) }\end{array}$ & $\begin{array}{l}\text { Starch } \uparrow \\
\text { (g.) }\end{array}$ & $\begin{array}{l}\text { Calcium } \\
\text { (mg.) }\end{array}$ & $\begin{array}{l}\text { Iron } \\
\text { (mg.) }\end{array}$ \\
\hline \multirow[t]{2}{*}{$\mathbf{I}$} & M. & C & 2267 & $7 r \cdot 3$ & $88 \cdot 2$ & 297 & - & - & 1261 & I I \\
\hline & & A & $213^{8}$ & $75 \cdot 1$ & $75^{\cdot 1}$ & - & I $17 \cdot 0$ & 152.9 & 1525 & 23 \\
\hline \multirow[t]{2}{*}{2} & M. & $\mathrm{C}$ & 2263 & $72 \cdot 3$ & $92 \cdot 2$ & 286 & - & 一 & 1252 & 12 \\
\hline & & A & 2181 & $69 \cdot 9$ & $94^{\circ} \circ$ & - & $106 \cdot 3$ & 139.0 & 1510 & 16 \\
\hline \multirow[t]{2}{*}{3} & M. & C & 1940 & $64 \cdot 6$ & $77 \cdot 9$ & 245 & 一 & 一 & 938 & 12 \\
\hline & & $\mathbf{A}$ & 1910 & $69 \cdot 6$ & $72 \cdot 3$ & - & $87 \cdot 6$ & 137.5 & 1210 & 19 \\
\hline \multirow[t]{2}{*}{4} & F. & C & 1690 & 50.9 & $66 \cdot 9$ & $22 I$ & - & - & 818 & 8 \\
\hline & & A & 1967 & $63 \cdot 6$ & $68 \cdot 8$ & - & $114^{\circ} 2$ & $141 \cdot 0$ & 1068 & I5 \\
\hline \multirow[t]{2}{*}{5} & M. & C & 2298 & $66 \cdot 6$ & $8 I \cdot 3$ & 325 & - & 一 & I I I 5 & II \\
\hline & & A & 2466 & $74 \cdot 0$ & $91 \cdot 4$ & - & $98 \cdot 7$ & $204 \cdot 9$ & 1280 & $2 I$ \\
\hline \multirow[t]{2}{*}{6} & F. & C & 1840 & $69 \cdot 3$ & $72 \cdot 3$ & 2,28 & - & $\overrightarrow{6}$ & 721 & 9 \\
\hline & & A & 1883 & $82 \cdot 9$ & $75^{\circ} 0$ & - & $86 \cdot 7$ & I $16 \cdot 6$ & 870 & I 3 \\
\hline \multirow[t]{2}{*}{7} & M. & C & 2172 & $73 \cdot 6$ & $96 \cdot 6$ & 252 & 一 & - & I I I O & 10 \\
\hline & & A & 1934 & 84.7 & 89.0 & - & 103.6 & 87.0 & 1320 & 18 \\
\hline \multirow[t]{2}{*}{8} & M. & C & 1907 & 84.9 & $57 \cdot 3$ & 263 & - & - & 467 & I 5 \\
\hline & & A & 1985 & $98 \cdot 2$ & $43 \cdot 2$ & - & $4 I \cdot 8$ & $2 \times 7 \cdot 5$ & 900 & 25 \\
\hline \multirow[t]{2}{*}{9} & F. & C & 2183 & $68 \cdot 3$ & 90.9 & 273 & - & 一 & $80 r$ & 12 \\
\hline & & A & 2193 & $88 \cdot 3$ & 85.5 & - & 95.5 & $150 \cdot 0$ & 1105 & 20 \\
\hline \multirow[t]{2}{*}{10} & M. & C & 2716 & $98 \cdot 2$ & $93 \cdot 2$ & 371 & - & - & 1353 & 14 \\
\hline & & A & 2470 & 109.3 & $77 \cdot 1$ & - & 100.0 & $202 \cdot 2$ & $175^{\circ}$ & 20 \\
\hline \multirow[t]{2}{*}{ II } & F. & C & 2235 & $79 \cdot 6$ & $91 \cdot 2$ & 274 & - & -.- & $1 \times 3 I$ & IO \\
\hline & & A & 2095 & $78 \cdot 0$ & 94.4 & - & 80.5 & $133^{\circ} 0$ & 1310 & 20 \\
\hline \multirow[t]{2}{*}{12} & M. & C & 2496 & $74 \cdot 6$ & $97 \cdot 9$ & 329 & - & - & $145^{8}$ & 10 \\
\hline & & A & 2595 & $83 \cdot 5$ & 115.8 & - & $125^{\circ} 0$ & 158.9 & 1445 & 17 \\
\hline \multirow[t]{2}{*}{ I 3} & M. & C & 2271 & $82 \cdot 9$ & 1119 & 233 & - & - & 1024 & II \\
\hline & & A & 2052 & $98 \cdot 1$ & $92 \cdot 3$ & - & $98 \cdot 5$ & $98 \cdot 0$ & 1230 & 15 \\
\hline \multirow[t]{2}{*}{14} & F. & C & 1879 & $53 \cdot 6$ & $72 \cdot 9$ & 252 & - & - & 898 & 8 \\
\hline & & A & 950 & $6 r \cdot 2$ & 73.4 & - & III. 6 & $121 \cdot I$ & 1893 & 18 \\
\hline \multirow[t]{2}{*}{ I 5} & M. & C & 2102 & $77 \cdot 3$ & $87 \cdot 6$ & 251 & - & - & I I 18 & 16 \\
\hline & & A & 1849 & $78 \cdot 3$ & 66.4 & - & $66 \cdot 7$ & 144.2 & I I I & 21 \\
\hline 16 & F. & C & 1691 & $61 \cdot 3$ & $5^{8 \cdot 9}$ & 229 & $\rightarrow$ & - & 921 & II \\
\hline & & $\mathbf{A}$ & I 666 & $67 \cdot 1$ & $60 \cdot 0$ & - & $86 \cdot 4$ & I 12.9 & 710 & 19 \\
\hline 17 & F. & C & 1360 & $54 \cdot 6$ & $53 \cdot 9$ & 164 & $\bar{c}$ & 一 & 825 & 9 \\
\hline & & A & 1294 & $5^{8.4}$ & $52 \cdot 5$ & - & $66 \cdot 6$ & $71 \cdot 9$ & 650 & 24 \\
\hline 18 & F. & C & 2051 & $64^{\circ} 9$ & $86 \cdot 2$ & 254 & - & - & 850 & 9 \\
\hline & & A & 2115 & $78 \cdot 3$ & $82 \cdot 9$ & - & $89 \cdot 0$ & $151 \cdot 8$ & 922 & 16 \\
\hline 19 & F. & C & 1679 & $59 \cdot 3$ & $60 \cdot 6$ & 224 & - & - & 654 & 9 \\
\hline & & A & 1803 & 83.5 & $65 \cdot 0$ & - & $6 I \cdot 5$ & I $36 \cdot 8$ & 790 & 22 \\
\hline 20 & $\mathrm{~F}$. & C & 2843 & $86 \cdot 6$ & 139.2 & $3 I X$ & - & - & I I I I & 14 \\
\hline & & A & 2506 & $90 \cdot 8$ & IOI.9 & - & $129 \cdot 5$ & I $57^{\circ} 0$ & 1290 & 16 \\
\hline 21 & F. & C & 1626 & $49 \cdot 3$ & $58 \cdot 3$ & 226 & - & - & 620 & 9 \\
\hline & & A & I 539 & $54^{\cdot} \cdot 1$ & $48 \cdot 0$ & - & 47.0 & $149^{\circ} I$ & 660 & 18 \\
\hline 22 & M. & C & 2361 & $74 \cdot 6$ & $82 \cdot 9$ & 329 & - & 一 & 1015 & 12 \\
\hline & & A & 2353 & $9 \mathrm{I} \cdot \mathrm{I}$ & $7 I \cdot 8$ & - & $106 \cdot 8$ & I 97.9 & $93^{\circ}$ & 17 \\
\hline 23 & M. & C & 2796 & $84^{\prime 2}$ & $129 \cdot 2$ & 324 & - & - & I 325 & 16 \\
\hline & & A & 2727 & $87 \cdot 7$ & $121 \cdot 0$ & $\overline{0}$ & 115.5 & I80.0 & 1205 & 43 \\
\hline 24 & F. & C & 2387 & $74 \cdot 6$ & 104.9 & 286 & - & - & 1415 & II \\
\hline & & A & 2471 & $82 \cdot 2$ & $121 \cdot 8$ & - & 95.5 & $145^{\circ} 0$ & 1450 & 17 \\
\hline 25 & F. & C & 1862 & $60 \cdot 9$ & $72 \cdot 3$ & 242 & - & $\cdots$ & 929 & 12 \\
\hline & & A & 1926 & $66 \cdot 1$ & $73 \cdot 1$ & - & $97 \cdot 0$ & $142 \cdot 7$ & 1033 & 18 \\
\hline 26 & M. & C & 2231 & $69 \cdot 9$ & $83 \cdot 9$ & 299 & $\overline{-}$ & - & 925 & 13 \\
\hline & & A & 2245 & 73.0 & $94^{\circ} 9$ & $\overline{0}$ & $86 \cdot 1$ & 163.0 & 993 & 21 \\
\hline 27 & F. & C & 2186 & $69 \cdot 6$ & $86 \cdot 6$ & 282 & - & - & 1100 & II \\
\hline & & A & 2262 & $73 \cdot 3$ & $98 \cdot 4$ & - & $95 \cdot 5$ & $152 \cdot 8$ & 875 & I9 \\
\hline 28 & M. & C & 2400 & $77 \cdot 6$ & 97.9 & 302 & - & - & I I 34 & I I \\
\hline & & A & 2199 & $80 \cdot 3$ & $76 \cdot 5$ & - & 117.8 & $15^{8 \cdot 1}$ & 969 & 20 \\
\hline
\end{tabular}




\begin{tabular}{|c|c|c|c|c|}
\hline \multicolumn{2}{|c|}{$\begin{array}{c}\text { Subject } \\
\text { No. Sex }\end{array}$} & $\begin{array}{l}\text { Method } \\
\text { of } \\
\text { survey }\end{array}$ & Calories & $\begin{array}{l}\text { Protein } \\
\text { (g.) }\end{array}$ \\
\hline 29 & F. & $\begin{array}{l}\text { C } \\
\text { A }\end{array}$ & $\begin{array}{l}1644 \\
1642\end{array}$ & $\begin{array}{l}5 \mathrm{I} \cdot 3 \\
59 \cdot 5\end{array}$ \\
\hline 30 & F. & C & 1618 & $45 \cdot 3$ \\
\hline & & $\mathbf{A}$ & 1579 & 50.5 \\
\hline $3 \mathrm{I}$ & F. & C & 1837 & $52 \cdot 9$ \\
\hline & & A & 1715 & $55^{.8}$ \\
\hline 32 & M. & C & 2371 & $79 \cdot 6$ \\
\hline & & $\mathbf{A}$ & 2245 & 90.4 \\
\hline 33 & F. & C & 1729 & $52 \cdot 6$ \\
\hline & & $\mathbf{A}$ & 1774 & $55 \cdot 8$ \\
\hline
\end{tabular}

Table I (cont.)

- $\mathrm{C}=$ calculation from food tables, $\mathrm{A}=$ chemical analysis.

+ These are the starch values actually found by analysis. They were increased by $21 \%$ for calculation of calorie values.

Table 2. Average daily nutrient values of diets eaten by thirty-three adults found by calculation from food tables and by chemical analysis

$\begin{array}{cccccc}\begin{array}{c}\text { Fat } \\ \text { (g.) }\end{array} & \begin{array}{c}\text { Carbohydrate } \\ (\mathrm{g} .)\end{array} & \begin{array}{c}\text { Sugar } \\ (\mathrm{g} .)\end{array} & \begin{array}{c}\text { Starch } \\ (\mathrm{g} .)\end{array} & \begin{array}{c}\text { Calcium } \\ (\mathrm{mg.})\end{array} & \begin{array}{r}\text { Iron } \\ (\mathrm{mg} .)\end{array} \\ 59.9 & 225 & - & - & 921 & 9 \\ 58.4 & - & 70.5 & 129.1 & 1061 & 12 \\ 63.6 & 216 & - & - & 679 & 5 \\ 68.0 & - & 104.5 & 80.4 & 683 & 15 \\ 75.3 & 237 & - & - & 657 & 9 \\ 77.1 & - & 87.9 & 99.5 & 755 & 10 \\ 96.9 & 295 & - & - & 956 & 14 \\ 98.0 & - & 53.7 & 167.0 & 904 & 13 \\ 73.6 & 214 & - & - & 791 & 10 \\ 82.0 & - & 75.3 & 112.0 & 995 & 14\end{array}$

\begin{tabular}{|c|c|c|c|c|c|c|}
\hline \multirow[b]{2}{*}{ Item } & \multirow[b]{2}{*}{$\begin{array}{l}\text { Value by } \\
\text { calculation }\end{array}$} & \multirow[b]{2}{*}{$\begin{array}{l}\text { Value by } \\
\text { analysis }\end{array}$} & \multicolumn{2}{|c|}{ Absolute difference } & \multicolumn{2}{|c|}{ Percentage difference } \\
\hline & & & Value & $\begin{array}{l}\text { Standard } \\
\text { deviation }\end{array}$ & Value* & $\begin{array}{l}\text { Standard } \\
\text { deviation }\end{array}$ \\
\hline $\begin{array}{l}\text { Calories (Cal.) } \\
\text { rotein (g.) }\end{array}$ & $\begin{array}{r}2088 \\
68\end{array}$ & $\begin{array}{r}2053 \\
76\end{array}$ & $\begin{array}{r}35 \\
-\quad 8 S\end{array}$ & $\begin{array}{l}141 \\
5.6\end{array}$ & $\begin{array}{c}2 \\
-10 S\end{array}$ & $\begin{array}{l}6.9 \\
7.2\end{array}$ \\
\hline$t(\mathrm{~g})$. & 84 & 81 & 3 & $13 \cdot 2$ & 5 & $16 \cdot 6$ \\
\hline urbohydrate (g.) & 265 & $255 \dagger$ & IOS & $20 \cdot 7$ & ${ }_{5} \mathrm{~S}$ & $8 \cdot 6$ \\
\hline ium (g.) & I.O & I.I & -0.1 & $I \cdot 12$ & $-7 S$ & $12 \cdot 0$ \\
\hline$(\mathrm{mg})$. & II & 19 & $-8 S$ & $4 \cdot 6$ & $38 \mathrm{~S}$ & 14.9 \\
\hline
\end{tabular}

S signifies that the difference is statistically significant.

- For each of the thirty-three diets, the values $\frac{\text { calculated - analysis }}{\text { analysis }} \times 100$ were found for each nutrient. The figures in this column are the averages of the figures thus found. They need not correspond exactly to the average differences expressed as percentages of the average values found by analysis.

$\dagger$ The starch values found by the methods adopted (Bransby et al. 1948) were increased by $21 \%$ for the reasons described in that paper.

Table 3. Distribution of percentage differences between values found by calculation from food tables and by chemical analysis*

\begin{tabular}{|c|c|c|c|c|c|c|c|c|c|c|c|c|}
\hline \multirow[t]{2}{*}{$\begin{array}{l}\text { Percentage } \\
\text { difference }\end{array}$} & \multicolumn{2}{|c|}{ Calories } & \multicolumn{2}{|c|}{ Protein } & \multicolumn{2}{|c|}{ Fat } & \multicolumn{2}{|c|}{$\begin{array}{l}\begin{array}{l}\text { Carbo- } \\
\text { hydrate }\end{array} \\
\end{array}$} & \multicolumn{2}{|c|}{ Calcium } & \multicolumn{2}{|c|}{$\underbrace{\text { Iron }}$} \\
\hline & + & - & + & - & + & - & + & - & + & - & + & - \\
\hline $0-9$ & 16 & I I & 2 & 15 & 7 & 11 & 18 & 4 & 3 & 7 & I & - \\
\hline $10-19$ & 4 & I & - & 13 & 2 & 6 & 8 & 2 & 2 & 12 & - & 3 \\
\hline $20-29$ & . & . & . & 3 & 4 & 3 & $\mathbf{I}$ & . & $\mathbf{I}$ & 5 & - & 5 \\
\hline $30-39$ & I & - & - & . & - & . & . & - & 2 & - & - & 7 \\
\hline 40 or more & . & . & . & . & . & . & . & . & . & 1 & . & I7 \\
\hline
\end{tabular}

- For each of the thirty-three diets, the values $\frac{\text { calculated - analysis }}{\text { analysis }} \times 100$ were found for each nutrient. It is on these figures that this table is based.

\section{DISCUSSION}

Little comment is necessary on the results for individual diets, except for the calcium values for subject no. 8. The value found by chemical analysis was $900 \mathrm{mg} . / \mathrm{day}$ and that by calculation $467 \mathrm{mg}$./day. No explanation of the large difference between these 
values can be given. 'The value found by calculation appears low, but the consumption of milk was only about 4 oz./day, almost no cheese was eaten, and the bread eaten (Hovis) was not fortified with calcium.

There was closer agreement between the average nutrient values found by calculation from food tables and by chemical analysis in this survey than in that previously reported (Bransby et al. 1948) for calories, fat, carbohydrate and calcium, but less agreement for protein and iron. The diets were drawn from homes in different localities, so that there was no possibility of the kind of systematic bias referred to in the previous study. The results of the present inquiry suggest that under similar field conditions the average values obtained for a group of people by calculation from food tables for all the nutrients concerned, except iron, are sufficiently precise for practical purposes. The values for iron show that calculation from food tables may give very wrong information.

The values found for individual diets, however, support the conclusion from the previous study, that the differences may be so large as to throw doubt on the usefulness for individual purposes of values found by calculation. Even for calories, the difference exceeded $10 \%$ for six of the thirty-three diets.

\section{SUMMARY}

1. Records of the weights of the foods eaten in 3 days were obtained from thirtythree adults living at home in Cambridge, Reading, London and Surrey. The nutrient values of these diets were calculated from tables of food composition. Duplicates of the diets eaten were collected and analysed for moisture, ash, calcium, iron, protein, fat, sugar and starch.

2. 'The average group values obtained for calories, protein, fat, carbohydrate and calcium by calculation were in sufficiently good agreement for practical purposes with those obtained by chemical analysis, but the value found for iron by chemical analysis was much greater than that found by calculation.

3. For individual diets the differences between the values found by calculation and by chemical analysis were in many instances so large as to throw doubt on the usefulness of the individual results obtained by calculation.

We are glad to express our appreciation to those who recorded and provided duplicates of their diets and those who helped with the organization of the inquiry, to the National Physical Laboratory for undertaking the computation, and to the Ministry of Food for providing the temporary ration cards. Two of the authors (C. G. D., J. K.) wish to thank the Government Chemist for permission to publish the analytical details given in this paper, and to express their appreciation of the co-operation of several members of the laboratory staff.

\section{REFERENCES}

Accessory Fond Factors Committee (1945). War Memor. med. Res. Coun., Lond., no. I4. Bransby, E. R., Daubncy, C. G. \& King, J. (1948). Brit. F. Nutrit. 2, 89.

McCance, R. A. \& Widdowson, E. M. (1946). Spec. Rep. ser. med. Res. Coun., Lond., no. 235,2 nd ed. 